\title{
Demographic Shifts and Segregation in Fargo and West Fargo, North Dakota Schools
}

\author{
Elizabeth A. Gilblom ${ }^{1}$, Sarah L. Crary ${ }^{1} \&$ Hilla I. Sang ${ }^{2}$ \\ ${ }^{1}$ Assistant Professor, School of Education, North Dakota State University, Fargo, USA \\ ${ }^{2}$ West Fargo, ND, USA \\ Correspondence: Elizabeth A. Gilblom, North Dakota State University, School of Education, FLC 210D NDSU \\ Dept. 2625, P.O. Box 6050, Fargo, ND 58108-6050, USA. E-mail: elizabeth.gilblom@NDSU.edu
}

Received: December 20, 2019 Accepted: January 21, 2020 Online Published: February 5, 2020

doi:10.5539/jel.v9n2p11 URL: https://doi.org/10.5539/jel.v9n2p11

\begin{abstract}
In this article, we examine how demographic changes in Fargo and West Fargo, North Dakota between 2000 and 2017, including the resettlement of refugees, have impacted equitable educational arrangements in Fargo Public Schools (FPS) and West Fargo Public Schools (WFPS). Drawing on multiple data sources, including North Dakota's Department of Public Instruction (DPI), Common Core of Data (CCD) available from the National Center for Educational Statistics (NCES) and block group data from the U.S. Census Bureau, we use Geographic Information Systems (GIS) to examine city and district level changes in the years 2000 and 2017. We also conduct descriptive statistics and a multivariate analysis of variance (MANOVA) to assess the relationships among Black student enrollment, performance on state tests and enrollment characteristics that include race and free and reduced lunch. Findings underscore the increasing isolation of students over time by race, socioeconomic background and language.
\end{abstract}

Keywords: access to education, education, geographic information systems, North Dakota, poverty, race, segregation, student achievement

\section{Introduction}

Although over sixty years have passed since the Brown v. Board of Education decision declared segregation in public education to be unconstitutional, school segregation continues to increase in the United States (Orfield, 2009; Orfield \& Frankenberg, 2014; Orfield, Frankenberg, \& Siegel-Hawley, 2016). Research since Brown indicates that segregated minority schools have detrimental short- and long-term effects on the students who attend them, and that most racially segregated schools enroll large shares of economically disadvantaged students (Fry, 2007; Linn \& Welner, 2007; Mickelson, Bottia, \& Southworth, 2008; Orfield, 2009). School racial and socioeconomic composition affects academic achievement, school discipline outcomes and school funding patterns (Langenkamp \& Carbonaro, 2018; Noltemeyer, Ward, \& Mcloughlin, 2015; Owens, Reardon, \& Jencks, 2016; Welch \& Payne, 2010).

The increasing segregation of public schools is especially concerning given that public school enrollment in the United States has grown substantially in size and diversity. Public schools are becoming less White and the student bodies have become poorer, trends that are likely to continue (Fry, 2007; Orfield, 2009). As racial and socioeconomic demographics around the country continue to evolve, school districts that have served predominantly White student populations are now serving larger populations of New Americans, people of color and English language learners (ELLs). Coupled with increasing segregation, these enrollment shifts generate questions of educational equity within the public education system.

The midwestern cities of Fargo and West Fargo, North Dakota are less commonly associated with racial and ethnic diversity. However, the rapidly changing composition of these cities that comprise an urban metro that lies on the west side of the Red River opposite of Moorhead, Minnesota, is shifting from an ethnically homogenous, predominantly White community, to a more racially and ethnically diverse community. Located 250 miles west of Minneapolis, Minnesota, Fargo and West Fargo seem unlikely international border towns situated on the domestic margin of North Dakota and Minnesota. But an examination of public schools in this transnational region is necessary as recent demographic shifts bring questions about educational equity in areas 
outside of large, urban districts.

While smaller cities around the country continue to witness demographic changes, limited research is available that details how demographic trends are transforming smaller, urban school districts and how well these districts are integrating newer student populations, including New Americans, ELLs, and students of color. The integration of newer student populations is a concern given that how administrators and educators respond to demographic shifts in their districts will have substantial and lifelong implications for students.

This study explores longitudinally the racial, socioeconomic, and linguistic demographic shifts that have occurred at the city and district levels in Fargo and West Fargo, North Dakota between 2000 and 2017. We begin this article with a literature review that details the socioeconomic and racial enrollment shifts and the increasing segregation of public schools at the national level. Next, we discuss the academic and social benefits of desegregated schools. The article then turns to an examination of the demographic shifts that have occurred at the local levels of Fargo and West Fargo, North Dakota. We use GIS maps and statistical analyses to illustrate trends and statistical relationships.

The research questions that guide this study are: How have demographic shifts between 2000 and 2017 altered the racial and socioeconomic landscape of Fargo and West Fargo, North Dakota and their respective school districts? To what extent do racial, socioeconomic, and linguistic isolation occur in Fargo Public Schools and West Fargo Public Schools? Does a relationship exist among Black student enrollment, science and ELA proficiency scores, and selected enrollment and community characteristics? The findings of this study underscore the isolation of students by race, socioeconomic background and language.

\section{Literature Review}

\subsection{National Public School Enrollment Trends in Socioeconomic and Racial Diversity}

Between 2000 and 2018, public school enrollment in the United States grew substantially in size and diversity. From 2000 to 2018, the number of American public school students has grown from 47.5 to 51 million (National Center for Education Statistics, 2019a). Over the same time period, the racial composition of schools shifted, falling from $61.1 \%$ White to $47.2 \%$ White, a $22.8 \%$ decrease (National Center for Education Statistics, 2019a). Conversely, the share of Hispanic students increased by $63.6 \%$, from $16.6 \%$ to $27.2 \%$, while the Black student enrollment slightly decreased (16.9\% to $15.1 \%$ ), and Asian student enrollment climbed (4.1\% to $5.2 \%$ ) (National Center for Education Statistics, 2019a).

Additionally, the proportions of students who qualify for a subsidized or free lunch, and ELLs in American public schools continues to grow. Data from the National Center for Education Statistics (2019b) indicate that from 2008 to 2017 , the share of students who qualify for a subsidized or free lunch increased by $22.7 \%$, from $41.8 \%$ to $51.2 \%$ of national enrollment. Concurrently, the proportion of students for whom English is not their first language rose by $12.8 \%$, from $8.5 \%$ to $9.5 \%$.

\subsection{Racial and Socioeconomic Segregation in Public Schools}

Although U.S. public schools are more racially diverse than ever before, they are also more segregated than they have been in the last 40 years (Orfield, 2009). Today, the average Black and Latino students attend a school that is more than $75 \%$ non-White, and segregated non-White schools are often segregated by poverty (Orfield, 2009). Research has underscored persistent links between racial segregation and poverty concentration (Fry, 2007; Orfield, 2009). In the 2005-2006 school year, $84 \%$ of segregated Black and Latino schools were also schools of concentrated poverty (Orfield, 2009). While most White students attend public schools in which less than $30 \%$ of the students are in poverty, Black and Latino students attend schools where, on average, about $58 \%$ of the students live in poverty (Orfield, 2009). Moreover, nationally, 40\% of Black and Latino students attend schools in which $70 \%$ to $100 \%$ of students are in poverty, compared to one in thirty White students and less than a tenth of Asian students (Orfield, 2009).

The Civil Rights Project at UCLA, a prominent organization devoted to civil rights research, refers to the phenomenon of the increasing isolation of higher concentrations of students of color and lower income students as 'double segregation' and the multilayered segregation pattern in which students are segregated by race, socioeconomic status, and language as 'triple segregation' (Ee, 2018). Orfield et al. (2016) state that lower income and students of color who attend disproportionately poor and racially segregated schools are offered fewer opportunities, including attending college and securing a well-paying job, than their White, middle class peers. As such, patterns of double and triple segregation in public schools perpetuates racial isolation and enduring social and economic inequality.

There are several reasons for this increased pattern of racially and socioeconomically isolated schools. Orfield et 
al. (2016) find that the sharp increase of students of color students enrolled in public schools coincides with the decrease of White students and results in the exposure of White students to other races. A larger share of students of color also come from lower socioeconomic backgrounds and they enroll in schools located in lower income neighborhoods. So, as White students are exposed to racially and socioeconomically mixed enrollments, students of color are getting less exposure to White students and more exposure to lower-income peers.

Fry (2007) found that in 1993-1994, one-third of all White students in the U.S. attended an "all-White" school, schools in which $95 \%$ or greater of the enrollment was White. By 2005-2006, one in five white students was attending a nearly all-White school (Fry, 2007). Conversely, $29 \%$ of Hispanic students and $31 \%$ of Black students attended schools in 2005-2006 that were "all-minority", schools in which fewer than 5\% of the students were White (Fry, 2007). The number of nearly all-minority public schools virtually doubled from 5,498 in 1993-1994 to 10,135 in 2005-2006 (Fry, 2007). Moreover, Orfield et al. (2016) found that between 1993 and 2013, the proportions of students who qualified for a free or reduced lunch increased for all racial groups. However, Black students and Latino students attended schools in which two-thirds of the students qualified for a subsidized lunch. Therefore, students of all races are increasingly exposed to lower-income peers, but students of color students have the most.

Additionally, Orfield et al. (2016) argue that increased segregation can also be attributed to less attention from the government on desegregation programs and policies and more attention was focused on strategies that try to promote equal opportunity through accountability policies, high-stakes testing, and school choice programs, including charter schools. Advocates of school choice programs argue that school choice policies promote racial integration because charter schools can attract students from a broader geographic range than traditional public schools (Chubb \& Moe, 1995; Finn, 1990; Hoxby, 1998; Nathan, 1996; Thernstrom \& Thernstrom, 2004; Wolf, Howell, \& Peterson, 2000). However, numerous scholars have not found this assumed integration taking place (Carnoy, Jacobsen, Mishel, \& Rothstein, 2005; Eckes \& Rapp, 2005; Gilblom \& Sang, 2019; Green, 2001; Kotok, Frankenberg, Schafft, Mann, \& Fuller, 2017; Lacireno-Paquet, Holyoke, Moser, \& Henig, 2002; Mickelson et al., 2008; Wells, 2009).

Reduced oversight of school district student assignment at the state and federal levels has also resulted in increased associations between school enrollment characteristics and residential segregation patterns (Reardon, Grewal, Kalogrides, \& Greenberg, 2012; Reardon \& Yun, 2005). Findings suggest that court-ordered desegregation plans for school districts are effective in reducing racial segregation, but school districts may rapidly resegregate to levels reflected in residential segregation patterns in the absence of continued court oversight (Reardon et al., 2012).

\section{Methodology}

National trends raise significant questions concerning educational opportunity and exclusion by social class, race, and geography at the local level, including Fargo and West Fargo, North Dakota, cities that are experiencing rapid demographic shifts. We examine the racial, socioeconomic and linguistic shifts that have occurred in Fargo and West Fargo, North Dakota and how these profound changes have affected educational opportunity in Fargo Public Schools (FPS) and West Fargo Public Schools (WFPS). We incorporate Geographic Information System (GIS) maps and state and federal data to study what has happened in Fargo and West Fargo, North Dakota within 17 years of demographic shifts, refugee resettlement and population growth.

\subsection{Data}

Data sources include the Common Core of Data (CCD) available from the National Center for Educational Statistics (NCES) between the 1999-2000 and 2017-2018 school years. The CCD data contained longitude and latitude information for each school and enrollment characteristics, including race, the number of refugees and English language learners (ELL) enrolled in each school, and the percentage of students in each school who receive free or reduced-price lunches in FPS and WFPS. North Dakota's Department of Public Instruction (DPI) provided student characteristics and assessment results for each school between 2007-2008 and 2017-2018, including the percent of students at each school who scored proficient on the English language arts (ELA) and science portions of the North Dakota State Assessment (NDSA), the statewide assessment that measures student performance against achievement standards. Census block group data from the American Community Survey (ACS), 5-year estimates available from the U.S. Census Bureau were downloaded for the years 2000, 2013, and 2017. Data include median home values, race, and language spoken at home. These years were selected because they had census block group data for Fargo and West Fargo. Census block level data were unavailable for Fargo and West Fargo. 


\subsection{Sample}

The sample included 35 public schools operating in FPS and WFPS during the time periods of 1999-2000 and 2016-2017 school years. Charter schools do not currently operate in North Dakota. The schools operating in FPS and WFPS during the 2016-2017 school year were grouped into quartiles based on the percentage of Black students enrolled in each school to determine if relationships exist among schools with higher proportions of Black students, academic performance and other school enrollment characteristics. Therefore, we investigate whether inequitable educational arrangements exist in FPS and WFPS by race, socioeconomic background and language. Table 1 identifies the number of each district's schools in each of the quartiles. Although we had district data for the school year 2018-2019, we used data from the 2016-2017 school year because the MANOVA, described below, incorporates census block group data from 2017, the most recent year available.

Table 1. Distribution of schools in FPS and WFPS in each quartile

\begin{tabular}{|c|c|c|c|}
\hline \multirow[b]{2}{*}{ Black Enrollment Quartiles } & \multicolumn{3}{|c|}{$\underline{\text { School Districts }}$} \\
\hline & $\underline{\text { Fargo }}$ & $\underline{\text { West Fargo }}$ & Total \\
\hline First Quartile $\leq 6.37 \%$ & 5 & 3 & 8 \\
\hline Second Quartile $6.38 \leq 12.61 \%$ & 5 & 5 & 10 \\
\hline Third Quartile $12.62 \leq 17.33 \%$ & 4 & 4 & 8 \\
\hline Fourth Quartile $>17.34 \%$ & 6 & 3 & 9 \\
\hline Total & 20 & 15 & 35 \\
\hline
\end{tabular}

\subsection{Statistical Analyses}

We conducted a multivariate analysis of variance (MANOVA) to test for significant relationships among the quartiles based on average Black student enrollment and the percentage of students proficient on the ELA and science portions of the NDSA, the percentages of students receiving a free or reduced lunch, refugees, immigrants, LEP, White, Hispanic, Asian, and students of two or more races enrolled at each school in FPS and WFPS. Additionally, we tested for significant relationships among the quartiles and the census block group characteristics of median income, median home values and the percentages of Black households living in the block groups surrounding each school in the sample. The alpha level of significance was set at $p<.05$. We also conducted descriptive statistics to illustrate patterns among student performance, race, socioeconomic background and language among the quartiles.

\section{Findings}

\subsection{Fargo And West Fargo: A Brief History of the School Districts}

The Fargo Township dates back to 1874, the same year as the establishment of FPS, School District 1 (Still, 1957). Fargo's founding coincided with the development of the Northern Pacific Railroad. As the railroad expanded west, a stop was needed on the west side of the of the Red River with the highest elevation possible to avoid floods (NDSU Archives, 2019; Still, 1957). In 1875, this stop became an official city named Fargo after William G. Fargo, a director of the Northern Pacific Railroad and co-founder of Wells Fargo Express Company (The City of Fargo, 2019; NDSU Archives, 2019).

The city of West Fargo began as a "Whistle Stop" named Haggart in 1871 that was located at the intersection of the Northern Pacific Railway and the Sheyenne River (City of West Fargo, 2019). In 1876, as more settlers arrived and the community grew, School District 6 was established and the first school was built (City of West Fargo, 2019). The school was erected at the corner of 13th Avenue and Sheyenne Street at the cost of $\$ 500$ (West Fargo Public Schools, 2019). The Village of West Fargo was officially incorporated in November 1930 (City of West Fargo, 2019).

In the 1950s, the two districts experienced reorganization with the incorporation of smaller districts that had enrollment declines (Bicentennial West Fargo-Riverside History Book Committee, 1977). One district, District 35, located between Fargo and West Fargo, had not operated a school since 1941 (West Fargo Public Schools, 2019). At the time of the one-room schoolhouse's closure, the residents of District 35 sold the schoolhouse and used the funds to pay the tuition of the remaining students to attend schools in FPS (Bicentennial West Fargo-Riverside History Book Committee, 1977). Since no school operated in District 35, the residents of this district did not pay school property taxes, which made the district a desirable location for business to operate (Bicentennial West Fargo-Riverside History Book Committee, 1977). This zone now located in the city of Fargo, features the area's largest shopping center, West Acres, and a large selection of heavy equipment dealers. 
In 1963, the superintendent of West Fargo successfully pushed for North Dakota House Bill 844, legislation that declared that any district that no longer had a school, must merge with another district (Bicentennial West Fargo-Riverside History Book Committee, 1977; Dissolution of School Districts, 1963). Once this bill passed, District 35 officially became part of WFPS, even though they had previously sent students to schools located in Fargo. WFPS only gained one student from the passage of this bill, but they profited over $\$ 1$ million in taxable valuation (West Fargo Public Schools, 2019). In 1973, North Dakota passed House Bill 1180 that solidified the school boundaries of West Fargo and Fargo (School District Boundary Changes, 1973; West Fargo Public Schools, 2019). These permanent boundaries also meant that Fargo could not reclaim land for FPS. During the 1950s, over 100 sections of land and several surrounding school districts were annexed by West Fargo (Bicentennial West Fargo-Riverside History Book Committee, 1977).

The incorporation of District 35 into District 6, WFPS, is an important event in the histories of Fargo and West Fargo. The area that was once District 35, and is now a commercial area named West Acres, is positioned within the boundaries of the city of Fargo. Figure 1 is a map that illustrates the city and school district boundaries for Fargo and West Fargo. The boundary of WFPS extends north beyond the city of Fargo and southeast past West Fargo's city limits. The WFPS boundary also bisects the city of Fargo, dividing the residents of Fargo into two school districts. The FPS boundary traces the North Dakota side of the Red River and the WFPS boundary. The green area in the map marks the area of the city of Fargo that is part of WFPS. Students who live in this section of Fargo attend schools in WFPS. Additionally, Lutheran Social Services (LSS) is marked on the map. The role of LSS is discussed in the sections of the article that follow. LSS is located in the green area of the map within the city of Fargo and the WFPS boundary. The state of Minnesota does not appear on the map but it is east of the FPS boundary (solid yellow line), which is also the Red River.

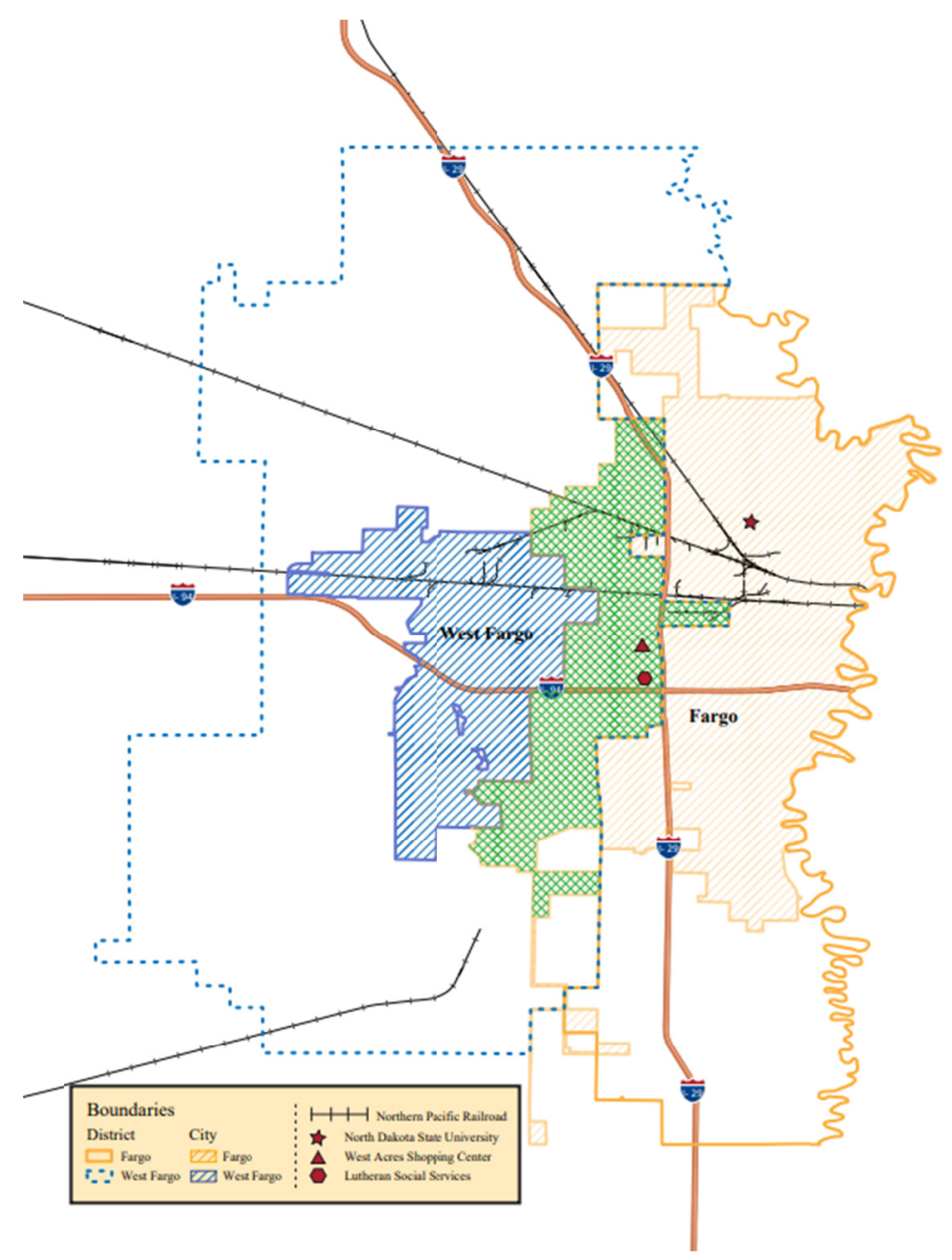

Figure 1. Map illustrating the current school district and city borders for Fargo and West Fargo, North Dakota 
The city and district boundaries have not changed since the passing of House Bill 1180 in 1973. Today, nearly half of WFPS local tax revenue comes from property in Fargo (Knutson, 2003). In 2003, 47\% of the property tax that benefitted West Fargo schools came from property located in Fargo due the configuration of boundaries (Cole, 2003). Although the common boundary of FPS and WFPS has not changed since the passing of House Bill 1180, even as both cities and districts have grown, there have been attempts to alter the boundaries. In 2003, Al Carlson, a Republican state representative from Fargo, introduced House Bill 1428 that would "require land annexed by a city to become part of that city's school district if the newly acquired land wasn't already in the district" (Knutson, 2003). About $90 \%$ of the land Fargo could annex is located in the WFPS, but this bill failed in the North Dakota House (Knutson, 2003).

\subsection{The Migration of Refugees to North Dakota}

The migration of refugees, or New Americans, into the United States, including the Great Plains, continues to transform the racial and ethnic landscape of public school districts. North Dakota is one state that is undergoing a demographic restructuring due to the influx of New Americans, individuals who are immigrants or refugees. This article uses the term 'refugee' rather than the more inclusive term 'New American' to distinguish between immigrants and refugees. A refugee is an individual who was forced to leave his or her own country due to war or violence or "has a well-founded fear of persecution for reasons of race, religion, nationality, political opinion or membership in a particular social group" (United Nations High Commissioner for Refugees, 2019). An immigrant is an individual who is not a U.S. citizen nor a U.S. national who was granted the right to work and live within the U.S by the United States Citizenship and Immigration Services and who may be able to live permanently in the U.S. (IRS, 2019). North Dakota is sixth in the nation and first in the Great Plains for per capita resettlement of refugees, a startling statistic given that North Dakota is ranked as $48^{\text {th }}$ in the nation for total state population (Gaber et al., 2004). Lutheran Social Services of North Dakota (LSS), the organization that provides resettlement services for refugees in Fargo, has settled nearly 5,000 refugees from 40 countries in Fargo since 1990 and $40 \%$ of those settled are children (McMullen, 2016).

\subsection{Refugee Resettlement in Fargo}

Refugees are the majority of the overall foreign-born population of Fargo. In the 1980s, 465 refugees were resettled in the Fargo-Moorhead area (Singer \& Wilson, 2006). By 2004, a total of 4,345 refugees were resettled (Singer \& Wilson, 2006). At the time of the 2000 U.S. Census, 2,718 of the 3,572 foreign born individuals (76.1\%) who entered the Fargo-Moorhead area between 1990 and 1999 were refugees (Singer \& Wilson, 2006). Since 2010, more than 11,300 racial and ethnic minorities have moved to Fargo, a figure nearly double than that of any other region of the state (North Dakota Census Office, 2017). Between 2007 and 2017, North Dakota has consistently settled more than 400 refugees every year, with the majority of them settling in Fargo. Between Oct. 1, 2018, and Sept. 31, 2019, 124 refugees were settled in North Dakota, of which 95 refugees were settled in Fargo, five in Grand Forks, and 24 in Bismarck (Olson, 2019).

As a state, North Dakota has served over 3,500 English language learners (Hageman, 2018). Fargo and West Fargo have $47 \%$ of the state's English language learner (ELL) population and $10 \%$ live in Grand Forks, a city 80 miles north of Fargo (Hageman, 2018). Both FPS and WFPS enroll significant numbers of ELLs. West Fargo Schools face some struggles to be ready for New Americans and refugees due to poor communication with LSS (Aksamit, 2000). FPS and WFPS sometimes receive two weeks' notice that LSS will be sending new students (Aksamit, 2000). Other times, schools are notified by the sponsoring families or not until they arrive at school (Aksamit, 2000).

\subsection{City and District Racial Enrollment Shifts}

The student enrollment demographics in FPS have evolved over time. Over the last 19 years, from 2000 to 2019 , the total enrollment of FPS has only slightly increased from 11,695 students to 12,434 students. However, during the same period, Black student enrollment increased seven-fold (1.9\% to $14.2 \%)$, Hispanic enrollment nearly tripled (1.6\% to $5.9 \%$, Asian enrollment doubled (2.1\% to 4.3\%), while White enrollment decreased $26 \%(91.8 \%$ to $67.6 \%$ ). Between 2008 and 2019, the share of ELLs in FPS increased by $8.3 \%$, from $8.81 \%$ to $9.53 \%$, while the percentage of students who are refugees decreased by $15.2 \%$, from $4.5 \%$ to $3.8 \%$, possibly due to the travel ban. Additionally, the percentage of students who are eligible for a free or reduced lunch doubled.

The student enrollment demographics in WFPS also shifted. Between 2000 and 2019, the total enrollment of WFPS increased $130 \%$, from 4,950 students to 11,556 students. Consequently, the number of schools operating in WFPS doubled, from nine schools in 2000 to 18 schools by 2019. The racial composition of WFPS has diversified over time. The percentage of Black students attending WFPS increased tenfold, from $1.2 \%$ in 2000 to $15 \%$ in 2019. Hispanic student enrollment has also increased substantially, from $1.3 \%$ in 2000 to $3.9 \%$ in 2019 . 
The percentage of students who qualified for a free or reduced lunch nearly doubled from $18.5 \%$ in 2000 to $31.2 \%$ in 2019. Additionally, Asian student enrollment grew fourfold between 2000 and $2019,0.7 \%$ to $3.6 \%$, respectively. However, the White student population declined between 2000 and 2019. In 2000, White students comprised $95 \%$ of student enrollment in WFPS. By 2019 , White enrollment decreased to $72.5 \%$ of total enrollment.

The GIS maps in Figure 2 compare block group data from the American Community Survey from 2000 and 2017 that illustrates the percentage of Black households residing in each census block group in Fargo and West Fargo. The maps also illustrate the percent of Black students enrolled in each school for the 1999-2000 and 2016-2017 school years. In 2000, only eight block groups out of a total of 82 block groups had Black households that comprised between 2.5\% and 7.5\% of all households living in all of Fargo and West Fargo. In West Fargo, the Black households living in each of the block groups comprised $2.5 \%$ or less of all households. Only three schools had Black enrollments between 2.5-7.5\% and one school had 7.5-15\% of total enrollment. Each of these schools were located in or near block groups with higher percentages of Black households. The corridor located in Fargo between the West Fargo city boundary and the WFPS boundary is one of the most diverse areas in these two cities. The most diverse census block group, one in which $25-50 \%$ percent of the households are Black households, is located north of LSS and the West Acres neighborhood, but no schools exists in this block.
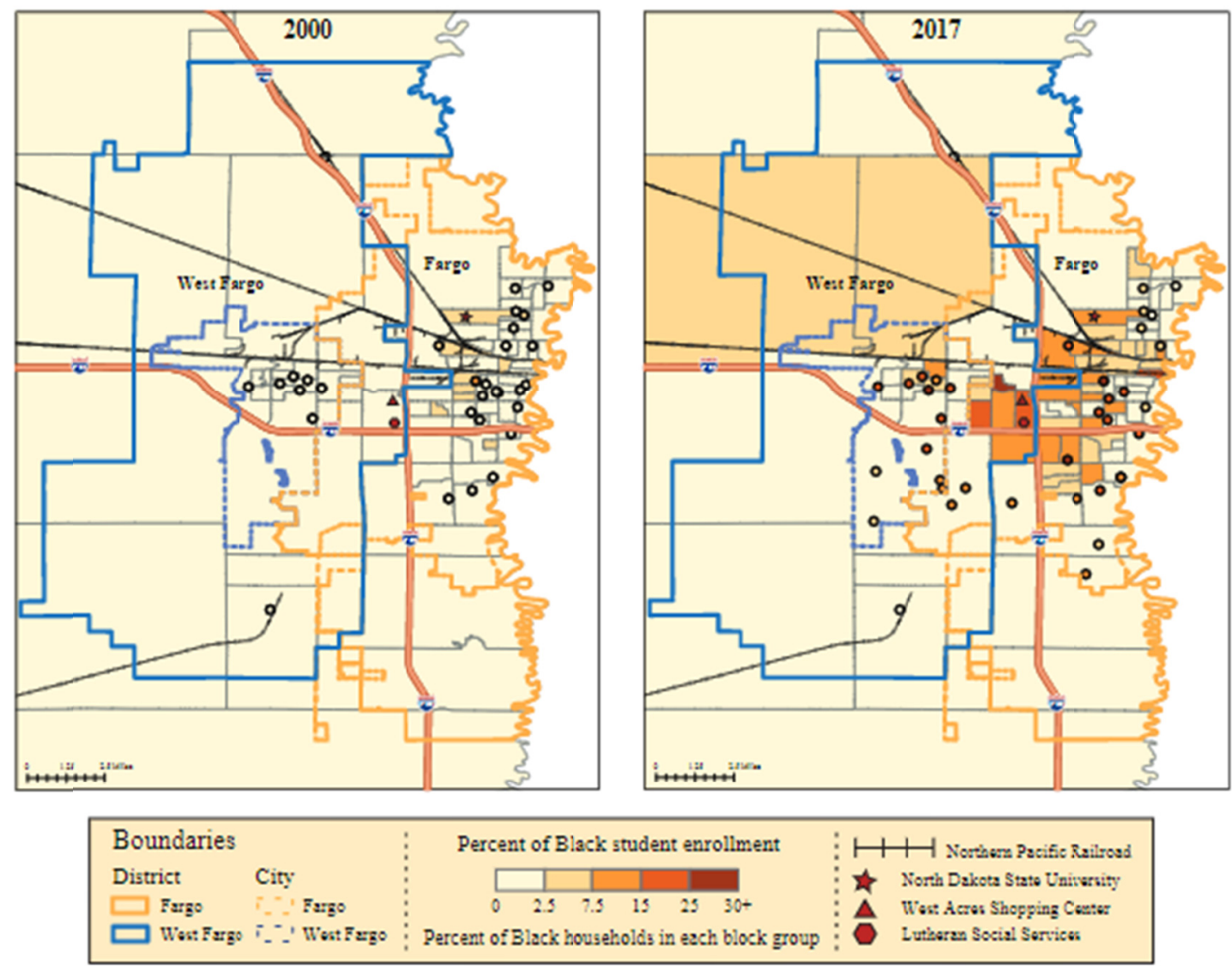

Figure 2. Maps comparing the percent of Black households in each block group and the percentage of Black students enrolled at each school for 2000 and 2017

In 2017, the block groups bordering the eastern side of I-29 have higher percentages of Black households while the block groups bordering Minnesota tend to have lower shares of Black households. As the number of Black households grew in Fargo and West Fargo, the schools became more diverse. While schools on the northern end of FPS changed slightly or not at all, schools in the middle and the southern ends of Fargo and nearly all of the schools in West Fargo had increased Black enrollments, with some schools reflecting Black enrollments of 25$35 \%$ of total enrollment. Census Bureau estimates for 2018 indicate that about 5.5\% Fargo's population of 
124,844, or 6,866 people, is comprised of Black individuals (U.S. Census Bureau, 2019a). In West Fargo, 2.1\% of the city's 36,566 individuals are Black individuals (U.S. Census Bureau, 2019a). Conversely, 84.5\% of Fargo and $90.9 \%$ of West Fargo is comprised of White individuals (U.S. Census Bureau, 2019a).

\subsection{City and District Socioeconomic Shifts}

The GIS maps in Figure 3 compare block group data that illustrate median home values of each block group in Fargo and West Fargo for the years 2000 and 2017. The maps also illustrate the percent of students in each school who receive a free or reduced lunch. In 2000, only two categories of median home value existed, homes that were valued at $\$ 100,000$ or less and homes that were valued between $\$ 100,000$ and $\$ 200,000$. The northern and southern areas of Fargo and West Fargo shaded in pink, areas north of the railroad tracks and south of I-94, are block groups with homes of more value while the central areas of the city, areas between the railroad tracks and I-94, have homes of less value. Some of the block groups in pink are associated with schools colored in dark pink, schools with the lowest category of free or reduced lunch, including the school in the Longfellow neighborhood, the two pink block groups in the northeast area that borders Minnesota. Also, the 2017 map indicates that three schools in Fargo serve enrollments in which $40-60 \%$ of students receive a free or reduced lunch while no schools in West Fargo serve free and reduced lunch enrollments over $40 \%$.
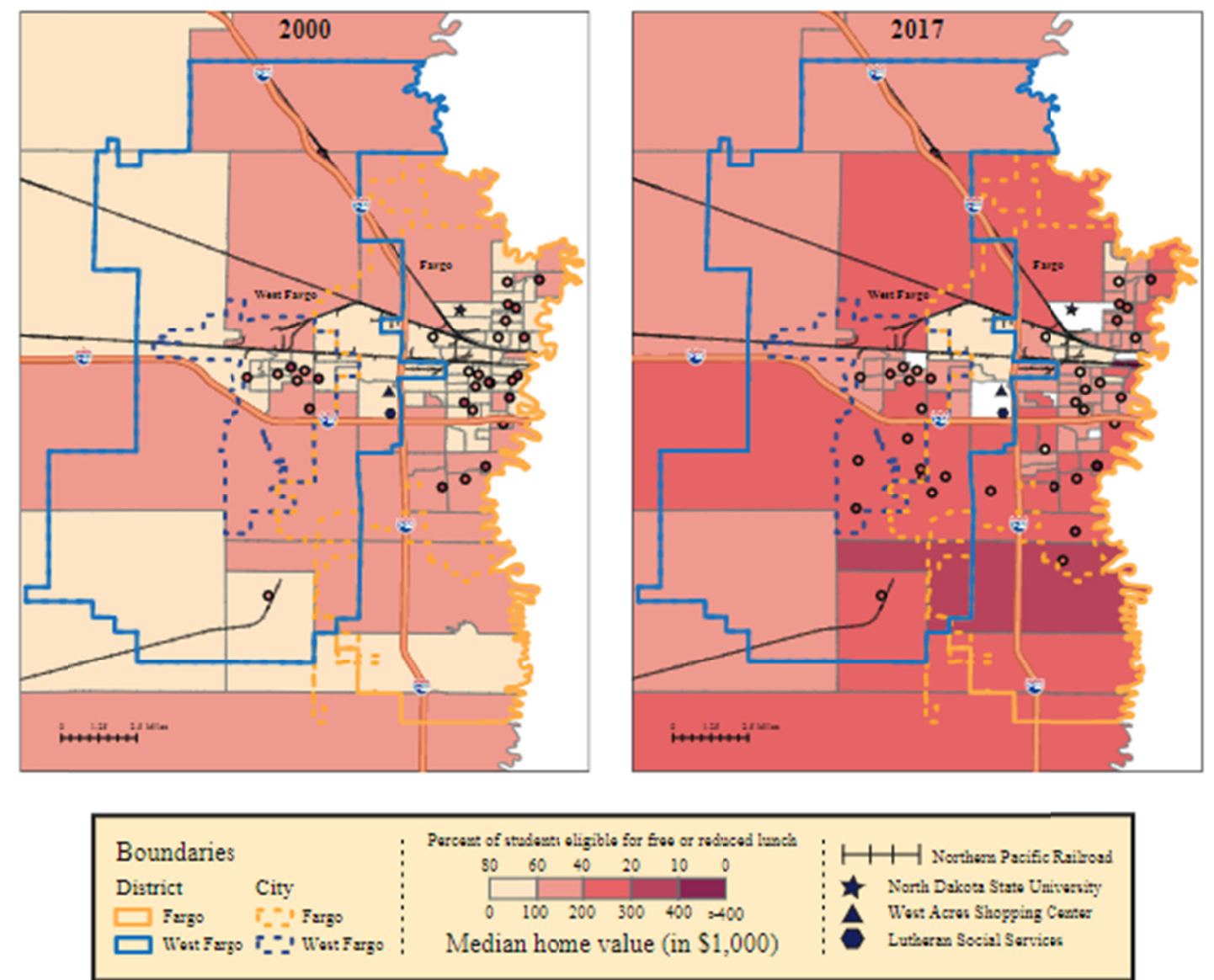

Figure 3. Maps comparing median home values of each block group and the percentage of students eligible for a free or reduced lunch enrolled at each school for 2000 and 2017

By 2017, the number of median home value categories and the percentage of free or reduced lunch categories expands to five. A block group on the southern end that extends across the school district boundary had homes valued at over $\$ 400,000$. An area located in Downtown Fargo also has homes valued at $\$ 400,000$ or more. The homes that were valued between $\$ 100,000$ and $\$ 200,000$ in 2000 are valued in 2017 between $\$ 200,000$ and $\$ 300,000$, including Longfellow. However, some block groups that had homes valued at \$100,000 or less in 2000 have not gained value, including the Madison neighborhood, the block group located west of the Downtown area with homes valued at $\$ 400,000$ and the block group located west of the I-29 between the train tracks. Additionally, 
two of the three Fargo schools that served free or reduced lunch enrollments between $40-60 \%$ in 2000 enroll between $60-80 \%$ in 2017. Also, two additional Fargo schools also have a free or reduced lunch enrollment between $60-80 \%$. While the school located in Longfellow serves a free or reduced lunch enrollment between 10$20 \%$ in 2017, a school located in southern Fargo serves fewer poor students. By 2017, students attending West Fargo schools have become poorer. WFPS primarily serve free or reduced lunch enrollments between $20-60 \%$, but no school has a free or reduced lunch enrollment greater than $60 \%$.

The areas marked in gray in the 2017 map are block groups that do not have owner-occupied homes and have no associated data. The gray area located south of the beige block group and west I-29 is the West Acres neighborhood. The city of Fargo zoned this area for general commercial use and multiple dwellings, including apartment complexes. LSS is located in this area. The gray area located east of the train tracks is part of North Dakota State University and the small gray area in West Fargo is zoned for agriculture. The two small gray areas located on either side of I-94 are areas zoned for multiple dwellings.

\subsection{City and District Linguistic Shifts}

The GIS maps in Figure 4 compare block group data that illustrate the percentage of households who speak a language other than English in their homes for the years 2013 and 2017. Block group data for 2000 for this language category is not available. The maps also illustrate the percentage of refugees attending each school in FPS and WFPS. In 2013, there are three census block groups in which $20-40 \%$ of the households living in the group speak a language other than English at home. One of these block groups is located in the West Acres corridor. By 2017, the percentage of households in the corridor who do not speak English in their homes increased. Of the census block groups inside the corridor, five block groups are shaded orange-red, indicating that $10-20 \%$ of the households speak a language other than English at home, and two are red, signifying that $20-50 \%$ of the households speak a language other than English at home. Four additional census block groups in Fargo are shaded red, as well.
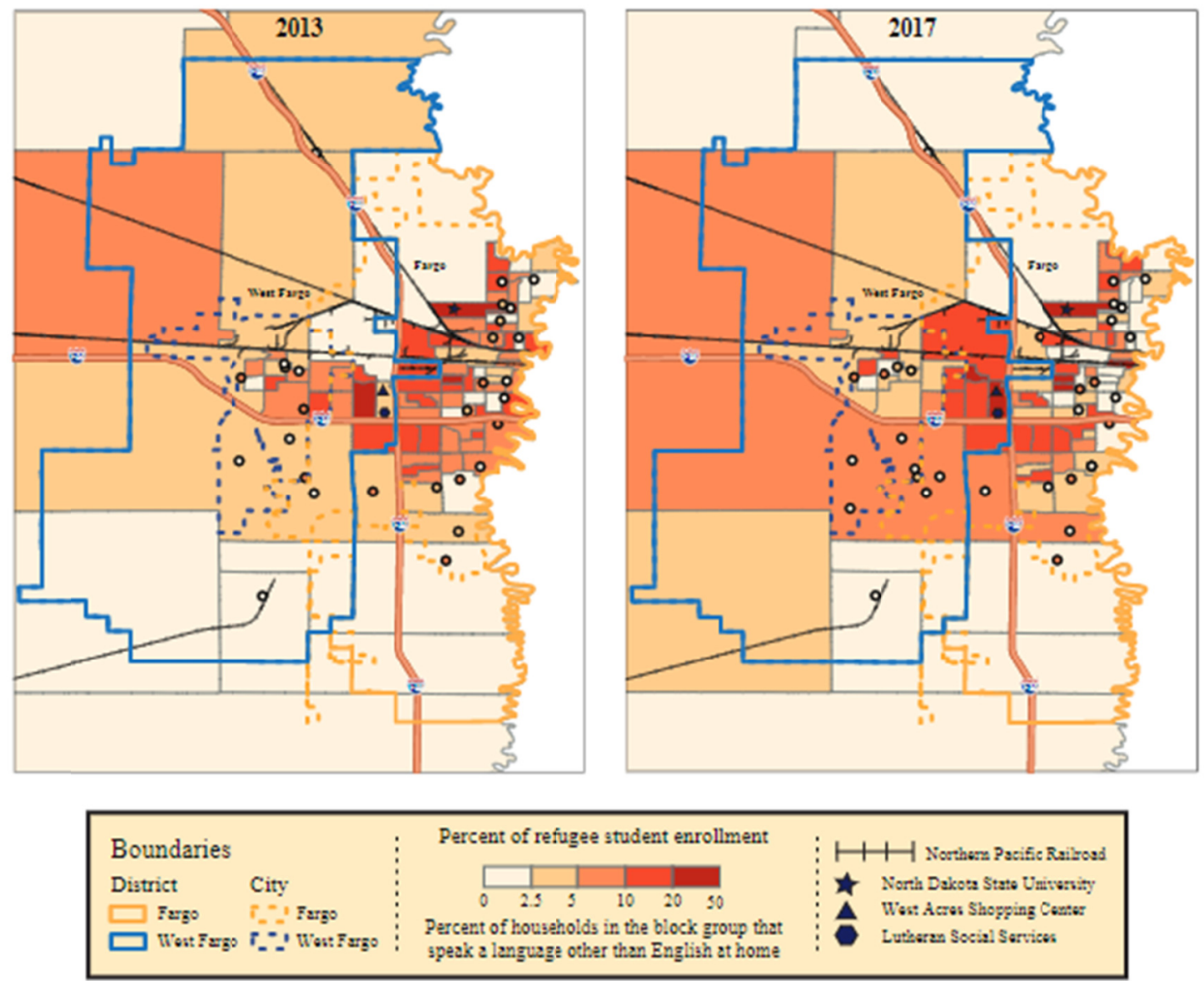

Figure 4. Maps comparing the percentage of households at the block group level who speak a language other than English at home and the percentage of refugees enrolled at each school for 2000 and 2017 
The 2017 map indicates that the large census block group south of I-94 and west of I-29 increased in the number of households who speak a language other than English at home, rising from $2.5-5 \%$ in 2013 to $5-10 \%$ in 2017 . Only two block groups located in West Fargo in 2017 have less than 2.5\% of non-English speaking households compared to 18 in Fargo. The number of non-English speaking households in Fargo declined in 2017. The majority of census block groups located on the border of Minnesota are shaded in white, representing the $2.5-5 \%$ level. Several of the block groups located on the east side of I-29 and north of I-94 decreased in the percentage of non-English speaking households. However, two additional block groups located south of I-94 increased and are now shaded in red, indicating the $10-20 \%$ level.

The percentage of refugees enrolled in FPS and WFPS has also shifted. In 2013, WFPS had five schools with refugee enrollments over 7.5\%, one of which was south of I-94. Four of five of these schools were in or bordering census block groups with higher percentages of non-English speaking households. FPS had seven schools with refugee enrollments over 7.5, three of which were south of I-94 and zero were located in the northern area of the district. Additionally, five of these schools were located in census block groups with higher percentages of non-English speaking households.

In 2017, one school in WFPS had refugee enrollment between $15-20 \%$ and two schools had between $10-15 \%$, all of which are located east of the corridor in the city of West Fargo. Also, two schools had refugee enrollments between 5-7.5\%. Although the number of schools south of I-94 increased, none of them had a refugee enrollment over $2.5 \%$ of total enrollment. In FPS, one school has a refugee enrollment between $15-20 \%$ and two between 10 $15 \%$. Although the northern area of FPS does have census block groups in which there are larger percentages of non-English speaking households, no school in that area has a refugee enrollment higher than $2.5 \%$. In fact, the schools with larger refugee enrollments are located in the center of the district.

\subsection{Racial and Socioeconomic Isolation in FPS and WFPS}

Table 2 presents the distribution of FPS racial enrollment for the school years 1999-2000, 2007-2008, and 20172018 by percent of students that receive a free or reduced lunch. This table indicates that, over time, Black, Hispanic, American Indian, Asian and students who receive free or reduced lunches are disproportionately attending schools in which $45 \%$ or more of the students receive free or reduced lunches. In other words, over the past 18 years, FPS have begun experiencing greater racial and socioeconomic isolation in which students who are either poor or are of color are more likely than White students to attend schools that enroll predominantly poor students and students of color.

Table 2. Distribution of FPS enrollment by percent of students that receive free or reduced lunch, 1999-2000, 2007-2008, and 2017-2018

\begin{tabular}{|c|c|c|c|c|c|c|c|}
\hline & $\underline{\mathrm{N}}$ & White & Black & $\underline{\text { Hispanic }}$ & $\begin{array}{l}\frac{\text { American }}{\text { Indian/ }} \\
\text { Alaska Native }\end{array}$ & $\frac{\text { Asian / }}{\underline{\text { Pacific }}} \frac{\text { Islander }}{\underline{\text { sand }}}$ & $\begin{array}{l}\text { Free and } \\
\text { Reduced } \\
\text { Lunch }\end{array}$ \\
\hline$\underline{\text { TFRL Enrollment }}$ & & \multicolumn{6}{|c|}{ Percent TFRL enrolled, 1999-2000 } \\
\hline 0 to less than $15 \%$ & 8 & $41 \%$ & $23 \%$ & $24 \%$ & $18 \%$ & $29 \%$ & $17 \%$ \\
\hline 15 to less than $30 \%$ & 9 & $49 \%$ & $50 \%$ & $50 \%$ & $53 \%$ & $53 \%$ & $56 \%$ \\
\hline 30 to less than $45 \%$ & 4 & $8 \%$ & $17 \%$ & $18 \%$ & $28 \%$ & $13 \%$ & $20 \%$ \\
\hline 45 to less than $60 \%$ & 1 & $2 \%$ & $9 \%$ & $9 \%$ & $2 \%$ & $6 \%$ & $7 \%$ \\
\hline \multirow[t]{2}{*}{ Grand Total } & 22 & & & & & & \\
\hline & & \multicolumn{6}{|c|}{$\underline{\text { Percent TFRL enrolled, 2007-2008 }}$} \\
\hline 0 to less than $15 \%$ & 5 & $24 \%$ & $17 \%$ & $10 \%$ & $8 \%$ & $27 \%$ & $10 \%$ \\
\hline 15 to less than $30 \%$ & 9 & $56 \%$ & $44 \%$ & $47 \%$ & $47 \%$ & $50 \%$ & $49 \%$ \\
\hline 30 to less than $45 \%$ & 5 & $16 \%$ & $26 \%$ & $30 \%$ & $31 \%$ & $12 \%$ & $25 \%$ \\
\hline 45 to less than $60 \%$ & 1 & $3 \%$ & $8 \%$ & $6 \%$ & $6 \%$ & $8 \%$ & $9 \%$ \\
\hline 60 to $75 \%$ TFRL & 1 & $1 \%$ & $5 \%$ & $7 \%$ & $9 \%$ & $2 \%$ & $7 \%$ \\
\hline \multirow[t]{2}{*}{ Grand Total } & 21 & & & & & & \\
\hline & & \multicolumn{6}{|c|}{ Percent TFRL enrolled, 2017-2018 } \\
\hline 0 to less than $15 \%$ & 3 & $10 \%$ & $3 \%$ & $5 \%$ & $6 \%$ & $4 \%$ & $3 \%$ \\
\hline 15 to less than $30 \%$ & 8 & $55 \%$ & $38 \%$ & $39 \%$ & $35 \%$ & $37 \%$ & $36 \%$ \\
\hline 30 to less than $45 \%$ & 4 & $20 \%$ & $24 \%$ & $30 \%$ & $29 \%$ & $34 \%$ & $26 \%$ \\
\hline 45 to less than $60 \%$ & 4 & $10 \%$ & $14 \%$ & $16 \%$ & $15 \%$ & $7 \%$ & $16 \%$ \\
\hline 60 to $75 \%$ & 3 & $5 \%$ & $20 \%$ & $10 \%$ & $15 \%$ & $18 \%$ & $19 \%$ \\
\hline Grand Total & 22 & & & & & & \\
\hline
\end{tabular}


In the 1999-2000 school year, $2 \%$ of White students attended schools in which $45-60 \%$ of students were receiving free or reduced lunches. This figure doubled to $4 \%$ by the $2007-2008$ school year and increased seven-fold to $15 \%$ in the 2017-2018 school year. In comparison, 9\% of Black students in the 1999-2000 school year attended schools in which 45-60\% of students were receiving free or reduced lunches. By the 2007-2008 and the 2017-2018 school years, $13 \%$ and $34 \%$ of Black students, respectively, attended schools with predominantly poor enrollments. Hispanic, American Indian and Asian students each show similar patterns in which they are more likely than White students to attend schools with higher proportions of poor enrollments. Over time, students who receive free or reduced lunches are likely to attend schools with higher enrollments of poor students, from 7\% in the 1999-2000 school year, to $16 \%$ in $2007-2008$, and $35 \%$ in 2017-2018. These figures correspond to the national trend discussed by Orfield et al. (2016) that students of all races are increasingly exposed to lower-income peers, but students of color have the most.

WFPS reflect trends parallel to FPS. Table 3 indicates that Black, Hispanic, American Indian, Asian and students who receive free or reduced lunches are disproportionately attending schools in which $30 \%$ or more of the students receive free or reduced lunches. During the 1999-2000 and 2007-2008 school years in WFPS, there were no enrollments in which $45 \%-65 \%$ of the enrollments were poor students. But, in the $1999-2000$ school year, $4 \%$ of White students attended schools in which $30-45 \%$ of students were receiving free or reduced lunches, a figure that tripled to $13 \%$ by the $2007-2008$ school year. In the $2017-2018$ school year, $46 \%$ of White students attend schools in which $30-60 \%$ of the enrollment were poor students.

Table 3. Distribution of FPS enrollment by percent of students that receive free or reduced lunch, 1999-2000, 2007-2008, and 2017-2018

\begin{tabular}{|c|c|c|c|c|c|c|c|}
\hline & $\underline{N}$ & White & Black & $\underline{\text { Hispanic }}$ & $\begin{array}{l}\text { American } \\
\underline{\text { Indian/ }} \\
\text { Alaska Native }\end{array}$ & $\begin{array}{l}\underline{\text { Asian / }} \\
\underline{\text { Pacific }} \\
\underline{\text { Islander }}\end{array}$ & $\begin{array}{l}\text { Free and } \\
\text { Reduced } \\
\underline{\text { Lunch }}\end{array}$ \\
\hline$\underline{\text { TFRL Enrollment }}$ & & $\underline{\text { Percen }}$ & arolled, & & & & \\
\hline 0 to less than $15 \%$ & 8 & $41 \%$ & $23 \%$ & $24 \%$ & $18 \%$ & $29 \%$ & $17 \%$ \\
\hline 15 to less than $30 \%$ & 9 & $49 \%$ & $50 \%$ & $50 \%$ & $53 \%$ & $53 \%$ & $56 \%$ \\
\hline 30 to less than $45 \%$ & 4 & $8 \%$ & $17 \%$ & $18 \%$ & $28 \%$ & $13 \%$ & $20 \%$ \\
\hline 45 to less than $60 \%$ & 1 & $2 \%$ & $9 \%$ & $9 \%$ & $2 \%$ & $6 \%$ & $7 \%$ \\
\hline \multirow[t]{2}{*}{ Grand Total } & 22 & & & & & & \\
\hline & & $\underline{\text { Percen }}$ & arolled, & & & & \\
\hline 0 to less than $15 \%$ & 5 & $24 \%$ & $17 \%$ & $10 \%$ & $8 \%$ & $27 \%$ & $10 \%$ \\
\hline 15 to less than $30 \%$ & 9 & $56 \%$ & $44 \%$ & $47 \%$ & $47 \%$ & $50 \%$ & $49 \%$ \\
\hline 30 to less than $45 \%$ & 5 & $16 \%$ & $26 \%$ & $30 \%$ & $31 \%$ & $12 \%$ & $25 \%$ \\
\hline 45 to less than $60 \%$ & 1 & $3 \%$ & $8 \%$ & $6 \%$ & $6 \%$ & $8 \%$ & $9 \%$ \\
\hline 60 to $75 \%$ & 1 & $1 \%$ & $5 \%$ & $7 \%$ & $9 \%$ & $2 \%$ & $7 \%$ \\
\hline \multirow[t]{2}{*}{ Grand Total } & 21 & & & & & & \\
\hline & & Percen & arolled, & & & & \\
\hline 0 to less than $15 \%$ & 3 & $10 \%$ & $3 \%$ & $5 \%$ & $6 \%$ & $4 \%$ & $3 \%$ \\
\hline 15 to less than $30 \%$ & 8 & $55 \%$ & $38 \%$ & $39 \%$ & $35 \%$ & $37 \%$ & $36 \%$ \\
\hline 30 to less than $45 \%$ & 4 & $20 \%$ & $24 \%$ & $30 \%$ & $29 \%$ & $34 \%$ & $26 \%$ \\
\hline 45 to less than $60 \%$ & 4 & $10 \%$ & $14 \%$ & $16 \%$ & $15 \%$ & $7 \%$ & $16 \%$ \\
\hline 60 to $75 \%$ & 3 & $5 \%$ & $20 \%$ & $10 \%$ & $15 \%$ & $18 \%$ & $19 \%$ \\
\hline Grand Total & 22 & & & & & & \\
\hline
\end{tabular}

Conversely, by $2017-2018,68 \%$ of Black students, $61 \%$ of Hispanic, $59 \%$ of American Indian, $52 \%$ of Asian and $70 \%$ of poor students attended schools in which $30-45 \%$ of students were receiving free or reduced lunches. These figures correspond to the national trend discussed by Orfield et al. (2016) that students of all races are increasingly exposed to lower-income peers, but students of color have the most exposure. The tables indicate that students of all racial categories and students with low socioeconomic backgrounds enrolled at WFPS are attending schools that are more racially and economically segregated than those who attend FPS.

\subsection{MANOVA Findings}

Multicollinearity tests conducted before the MANOVA were performed revealed that the following independent variables had correlation coefficients of .80 and above that indicated higher degrees of correlation and were subsequently omitted from the MANOVA (Tabachnik \& Fidell, 2013): percentage of immigrant and LEP enrollments, Hispanic students, White students, and students receiving a free or reduced lunch. 
A non-significant Box's $M$ test $(p=.600)$ indicates homogeneity of covariance matrices of the dependent variables across the four quartiles. The Levene's Test of Equality of Error Variances was significant for the percentage of Black households living in the block groups surrounding each school $(p<.001)$, the percentage of refugees enrolled $(p<.001)$, and the percentage of Asian students enrolled $(p=.012)$, indicating that the assumption of homogeneity of variances is violated. Given this, the level of significance for these variables was adjusted to a more conservative alpha of $p<.01$ (Tabachnik \& Fidell, 2013). As the Levene's test was violated, the Pillai's Trace statistic was used to determine whether significant differences existed among the quartiles in terms of the independent variables (Tabachnick \& Fidell, 2013).

The multivariate effect was significant, Pillai's Trace $=1.37, F(24,75)=2.62, p<.001$. A multivariate partial $\eta 2$ $=.50$ indicates that approximately $50 \%$ of multivariate variance of the dependent variables is associated with the group factor of the percentage of Black students enrolled.

Table 4 displays the results of the Univariate tests indicated that there were significant differences across the four quartiles on the percentage of students proficient in science, $F(3,30)=6.09, p=.002$ partial $\eta 2=.38$; the percentage of students proficient in ELA, $F(3,30)=4.21, p=.013$, partial $\eta 2=.30$; the percentage of enrolled students who are two or more races $F(3,30)=3.56, p=.03$, partial $\eta 2=.26$; and median home value, $F(3,30)=$ $3.25, p=.035$, partial $\eta 2=.25$. The percentage of enrolled refugees was significant at the alpha level of $\mathrm{p}<.01$, $F(3,30)=13.83, p<.001$, partial $\eta 2=.58$.

Table 4. MANOVA results for each of the four black enrollment quartiles.

\begin{tabular}{|c|c|c|c|c|c|c|c|c|c|c|c|c|}
\hline & \multicolumn{2}{|c|}{ First Quartile } & \multicolumn{2}{|c|}{ Second Quartile } & \multicolumn{2}{|c|}{ Third Quartile } & \multicolumn{2}{|c|}{ Fourth Quartile } & & & & \\
\hline Percent Black & $\leq 6.37 \%$ & & $6.38 \leq 12$ & $61 \%$ & $12.62 \leq$ & $7.33 \%$ & $>17.34 \%$ & & & & & \\
\hline 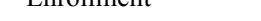 & & & & & & & & & & & & \\
\hline $\mathrm{N}$ of schools & 7 & & 10 & & 8 & & 9 & & & ANOV & & \\
\hline & Mean & $\underline{\mathrm{SD}}$ & Mean & $\underline{\mathrm{SD}}$ & Mean & $\underline{\mathrm{SD}}$ & Mean & $\underline{\mathrm{SD}}$ & $\underline{\mathrm{N}}$ & $\underline{F}$ & $\underline{P}$ & Tukey \\
\hline Achievement & & & & & & & & & & & & \\
\hline Science Proficiency & $77.4 \%$ & $5.5 \%$ & $65.2 \%$ & $10.0 \%$ & $65.9 \%$ & $7.6 \%$ & $57.8 \%$ & $11.2 \%$ & 34 & 6.086 & 0.002 & $1>3>2>4$ \\
\hline ELA Proficiency & $58.3 \%$ & $7.1 \%$ & $52.8 \%$ & $9.5 \%$ & $55.3 \%$ & $10.2 \%$ & $41.8 \%$ & $12.6 \%$ & 34 & 4.207 & 0.013 & $1>3>2>4$ \\
\hline Enrollment & & & & & & & & & & & & \\
\hline Percent Asian & $1.7 \%$ & $1.6 \%$ & $2.5 \%$ & $1.3 \%$ & $5.2 \%$ & $1.9 \%$ & $5.1 \%$ & $4.4 \%$ & 34 & 3.804 & 0.020 & $3>4>2>1$ \\
\hline Percent Two or More & $\mathrm{e} 2.1 \%$ & $1.0 \%$ & $3.9 \%$ & $2.7 \%$ & $2.3 \%$ & $1.4 \%$ & $4.9 \%$ & $2.3 \%$ & 34 & 3.56 & 0.023 & $4>2>3>1$ \\
\hline Races & & & & & & & & & & & & \\
\hline Percent Refugees & $0.2 \%$ & $0.4 \%$ & $1.2 \%$ & $1.0 \%$ & $8.0 \%$ & $4.8 \%$ & $8.8 \%$ & $4.9 \%$ & 34 & 13.84 & 0.001 & $4>3>2>1$ \\
\hline Community & & & & & & & & & & & & \\
\hline $\begin{array}{l}\text { Median Home Value } \\
\text { (\$) }\end{array}$ & 235,843 & 65,726 & 229,160 & 67,523 & 254,913 & 72,158 & 166,878 & 39,654 & 34 & 3.254 & 0.035 & $3>1>2>4$ \\
\hline $\begin{array}{l}\text { Median Household } \\
\text { Income (\$) }\end{array}$ & 87,181 & 26,784 & 76,097 & 31,485 & 80,783 & 24,005 & 63,877 & 18,911 & 34 & 1.182 & 0.333 & $1>3>2>4$ \\
\hline$\%$ Black Households & $\mathrm{s} 1.8 \%$ & $2.1 \%$ & $2.8 \%$ & $2.7 \%$ & $1.3 \%$ & $1.1 \%$ & $5.3 \%$ & $5.8 \%$ & 34 & 2.245 & 0.103 & $4>2>1>3$ \\
\hline
\end{tabular}

The median household income of the block groups surrounding each school were not statistically significant at the alpha level of $p<.05$. The percentage of African American families living in the census block groups surrounding each school and the percentage of enrolled Asian students were not statistically significant at the alpha level of $p$ $<.01$.

Tukey's post hoc tests indicated that the first quartile, the quartile with the fewest enrolled Black students had the highest science and ELA proficiency scores, and the lowest percentages of enrolled students who are refugees or who are two or more races. Although nonsignificant, the first quartile also had the highest median household incomes and the lowest percentage of enrolled Asian students.

The fourth quartile, the quartile with the highest percentage of Black students, had the lowest science and ELA proficiency scores, the highest percentages of enrolled refugees or students who are two or more races, and the lowest median incomes. Although nonsignificant, this quartile also had the lowest median home values and the highest percentage of African American households living in the block groups surrounding each school.

\subsection{Descriptive Statistics Findings}

Although immigrant enrollments, EL enrollments, and the percentage of students receiving a free or reduced lunch 
were omitted from the MANOVA, other analyses were conducted to provide additional information and guide possible future studies on these and related variables. Figure 5 illustrates the percentages of immigrants and ELLs in each quartile. This figure suggests that as the share of Black enrollments increases in each quartile, the proportion of immigrant and EL enrollments increases. The first quartile, the group with the highest science and ELA proficiency scores, the highest median household incomes, and the fewest proportion of students of color also has the fewest share of immigrant and ELL enrollments. Conversely, the fourth quartile, the group with the lowest proficiency levels, the greatest diversity and the lowest median incomes, has the highest percentages of immigrant and ELL enrollments.

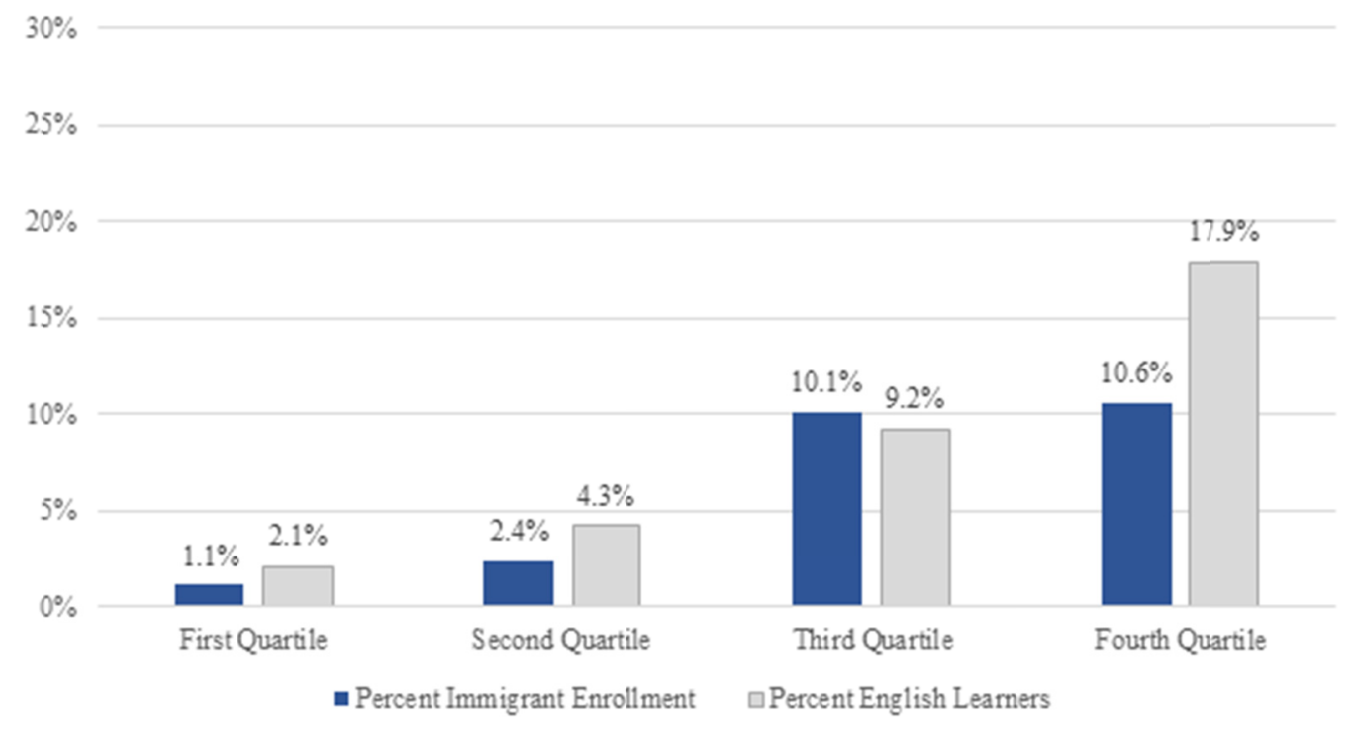

Figure 5. Percent of immigrants and English learners' enrollments by Black enrollment quartiles Note. FPS and WFPS, AY 2016-2017.

Figure 6 illustrates the percentages of students who are eligible for a free or reduced lunch by the quartiles. This figure suggests that as the share of Black enrollments increases in each quartile, so does the proportion of students who are eligible for a free or reduced lunch. Figures 5 and 6 both illustrate the increasing racial, socioeconomic and linguistic isolation, otherwise known as triple segregation, occurring in FPS and WFPS. Students who are White are less exposed to students of color, English learners and poverty while students of color are generally grouped with one another in lower performing, higher poverty schools.

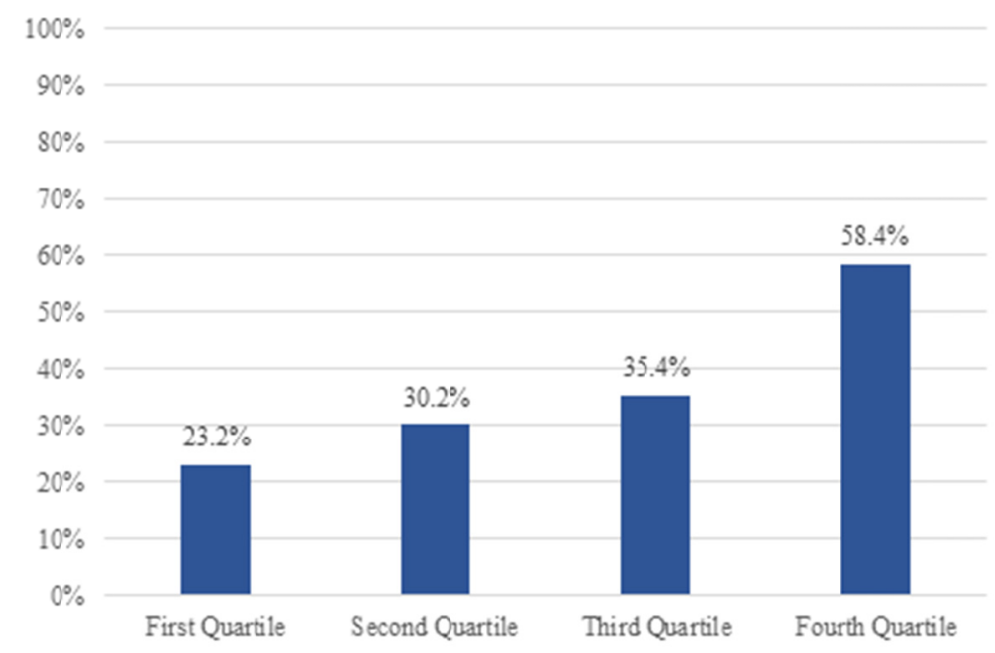

Figure 6. Percentage students who are eligible for free or reduced lunch by Black enrollment quartiles Note. FPS and WFPS, AY 2016-2017. 


\section{Discussion}

The maps and statistics we present underscore the isolation of students by race, socioeconomic background and language in FPS and WFPS. Over time, isolation by race and socioeconomic background has become more severe. The maps illustrate economic, racial and linguistic changes that have taken place within the cities of Fargo and West Fargo and within their school districts between 2000 and 2017. The statistical analyses indicate that students who are Black are likely to attend schools with higher percentages of refugees, ELs, immigrants, students of color and students who receive a free or reduced lunch. Additionally, schools that enroll higher shares of students of color, immigrants and refugees, and students who receive a free or reduced lunch tend to have lower science and ELA proficiency scores. Schools who serve higher shares of White students and lower enrollments of refugees, ELs, immigrants and students who receive a free or reduced lunch, or that are located in census block groups with higher median incomes, tend to have higher science and ELA proficiency scores.

Schools with less diverse student enrollments tend to be located on the northern section of FPS and in census block groups closer to the Minnesota border. Those areas are the areas with higher home values, fewer Black households and predominantly English-speaking households. Generally, WFPS serves a more racially and socioeconomically diverse enrollment than FPS. Although the census block groups in West Fargo are predominately English speaking, all except for two, individuals who live in the corridor located in Fargo attend schools in WFPS. As a result, WFPS have higher shares of refugee enrollments. Schools with higher shares of refugees tend to also serve higher Black, immigrant, and ELL enrollments and larger shares of students who receive a free or reduced lunch. The schools in WFPS that are located south of I-94 tend to have higher Black enrollments, larger enrollments of students who receive a free or reduced lunch, but smaller shares of refugees.

While the results indicate substantial inequitable arrangements for students based on race, socioeconomic background and language within FPS and WFPS, we have a limited understanding of how these arrangements occurred. The racial diversification of schools in West Fargo may be partially attributed to the resettlement of larger percentages of refugees in Fargo who live in the corridor. But, what is less understood is how enrollment boundaries have shaped enrollments throughout FPS and WFPS when the overall student enrollment is racially diversifying.

Enrollment boundary changes frequently occur when cities experience population growth. As cities grow and their respective school enrollments begin to stretch the capacity of existing buildings, new schools are built and enrollment boundaries are redrawn. Residential segregation is linked to school segregation because many school districts draw enrollment boundaries around immediate neighborhoods (Sohoni \& Sapporito, 2009). When enrollment boundaries are drawn in this manner, schools become segregated because segregated neighborhoods produce segregated schools. Therefore, school attendance zones essentially determine the racial composition of school enrollment (Saporito \& Sohoni, 2006). Oftentimes, racially segregated schools are also socioeconomically segregated, arrangements that are often linked to decreased student performance, teacher quality lower graduation rates, and higher dropout rates (Balfanz \& Legters, 2004; Linn \& Welner, 2007; Orfield \& Lee, 2005; Swanson, 2004). Orfield and Eaton (1997) and Clark (1987) argue that school districts have drawn attendance boundaries to deliberately intensify segregation and undermine integration efforts. Moreover, evidence suggests that districts continue to draw racially inequitable boundaries (Orfield \& Luce, 2009; Siegel-Hawley, 2013).

FPS and WFPS continue to experience school boundary issues as West Fargo's population continues to grow, and Fargo's population continues to shift southward. In 2017, West Fargo faced push back on their proposed plan to redraw elementary school enrollment boundaries to balance enrollments at two elementary schools while a third school would open the following year, a change that affected about 200 elementary school students (Reuer, 2017). The controversy arose due to the division of neighborhoods. For example, individuals who lived on either side of the same street were sometimes assigned to different schools (Pool, 2017). Also, students who attended one school the previous year were assigned to a different school the following year (Pool, 2017). This boundary change was perceived as a "one-year fix" by the superintendent who remarked that West Fargo would undergo "a steady diet of boundary changes in the next few years" as the district experiences population growth (Reuer, 2017).

In 2019, Fargo faced challenges in evaluating how the current boundaries could be altered to reduce overcrowded buildings (Amundson, 2019). Schools located in FPS have higher enrollments and crowded southside schools while northside schools, areas with predominantly White Households, are under-enrolled. A 40-member task force was charged with developing suggestions to draw new enrollment boundaries in FPS, with the final recommendation determined by the Board of Education (Amundson, 2019). The top five priorities for guiding the new boundaries were to: 1) Provide equitable space, resources and staff, 2) Strive for equitable number of students per classroom, 3) Strive for balance with a socioeconomic mix, 4) Set attendance areas to make best use 
of tax dollars, and 5) Work with area planners to consider stability (Amundson, 2019 p. A1). As of June 2019, the task force had not reached at least an $80 \%$ consensus on a school enrollment boundary recommendation, the percentage required for the recommendation to be made to the Board of Education (Fargo Public Schools, 2019).

School reassignment processes present significant opportunities for school districts to thoughtfully consider their evolving community demographics (Siegel-Hawley, 2013). But, when districts redraw enrollment boundaries in a way that exacerbates racial integration, educational gerrymandering ensues (Orfield \& Luce, 2010). Richards (2014) argues that gerrymandered enrollment boundaries "provide an additional layer of stratification that exacerbates existing patterns of residential segregation" (p. 1121). However, attendance zones can be gerrymandered for the purpose of promoting integration. Without a strong commitment to diversity and integration, the opportunity to develop district wide diverse learning environments that promote positive educational outcomes and social benefits for all students may pass and isolation linked to redrawn boundaries can occur. For this reason, further research that investigates the role that enrollment boundaries have played in FPS and WFPS as mechanisms that perpetuate segregation and promote inequitable educational arrangements is necessary.

\section{Limitations}

Data for this study were taken from secondary sources so the authors had no control over the operationalized definitions and collection methods of the variables. For example, by definition, a census block group encompass an area that contains between 600 and 3,000 people (U.S. Census Bureau, 2019b). Some areas in FPS and WFPS are sparsely populated so the block groups will be larger than the typical block groups. As a result, some larger block groups overlap both school districts and this may affect the calculation of the community demographics.

\section{Conclusion}

Segregation is still an issue in public schools, a fact that is especially problematic given that enrollment diversifying across the nation. The rapidly changing compositions of Fargo and West Fargo, North Dakota, a once ethnically homogenous, predominantly White metro area, is transforming public school enrollment. But, as FPS and WFPS are changing in terms of race, class and language, these districts are producing unequal school arrangements that have lifelong impacts on students. Although FPS and WFPS are not regarded as the typical urban school district that grapples with segregation, predominantly White districts across the nation are becoming more diverse and they will need to determine how to best manage these changes. Becoming aware that inequitable school arrangements exist based on race, class or language is a first step towards progress. Determining how those arrangements have occurred may be a critical second step towards promoting an equitable educational landscape.

\section{References}

Aksamit, N. (2000, August 20). Refugee student numbers growing, West Fargo schools preparing for 33 percent increase this fall. The Forum of Fargo-Moorhead.

Amundson, B. (2019, May 1). Fargo school boundaries again studied; Task force ranks guidelines to help elected officials tackle ongoing imbalances (p. A1). The Forum of Fargo-Moorhead.

Ayscue, J. B., Frankenberg, E., \& Siegel-Hawley, G. (2017). The complementary benefits of racial and socioeconomic diversity in schools. Washington, DC: The National Coalition on School Diversity.

Balfanz, R., \& Legters, N. E. (2004). Locating the dropout crisis: Which high schools produce the nation's dropouts? In G. Orfield (Ed.), Dropouts in America: Confronting the graduation crisis (pp. 57-84). Cambridge, MA: Harvard Education Press.

Bicentennial West Fargo-Riverside History Book Committee. (1977). Thru the Years to '76. J\&M Printing.

Carnoy, M., Jacobsen, R., Mishel, L. R., \& Rothstein, R. (2005). The charter school dust-up: Examining the evidence on enrollment and achievement. Washington, DC: Economic Policy Institute. https://doi.org/10.1086/589122

Chubb, J., \& Moe, T. (1995). Politics, markets, and equality in schools. In P. Harker (Ed.), The service productivity and quality challenge. International studies in the service economy (vol. 5, pp. 435-469). Springer. https://doi.org/10.1007/978-94-011-0073-1_17

City of West Fargo. (2019). History of West Fargo: West Fargo. ND. Retrieved from https://www.westfargond.gov/881/History-of-West-Fargo

Clark, W. A. V. (1987). Demographic change, attendance area adjustment and school system impacts. 
Population Research and Policy Review, 6, 199-222. https://doi.org/10.1007/BF00122782

Cole, J. (2003, February 8). Sides argue fairness on school border bill (p. A10). The Forum of Fargo-Moorhead.

Derman-Sparks, L., \& Ramsey, P. (2006). What if all the kids are White? Anti-bias multicultural education with young children and families. New York, NY: Teachers College Press.

Dissolution of School District, ND Stat. $§ ~ 15-22-21-22$ (1963).

Eckes, S., \& Rapp, K. (2005). Charter schools: Trends and implications. In E. St. John (Ed.), Readings on education (vol. 19, pp. 1-26). AMS Press.

Ee, J. (2018). Segregation and unequal academic outcomes in Buffalo's criteria-based schools. In. G. Orfield \& J. B. Ayscue (Eds.), Discrimination in elite public schools: Investigating Buffalo (pp. 55-73). New York, NY: Teachers College Press.

Fargo Public Schools. (2019). Fargo public schools building capacity \& usage task force: Meeting notes. Retrieved

from https://www.fargo.k12.nd.us/site/handlers/filedownload.ashx?moduleinstanceid=4495\&dataid=14261\&File Name=June 4 Meeting Notes.pdf

Finn, C. E. Jr. (1990). Why we need choice. In W. L. Boyd \& H. J. Walberg (Eds.), Choice in education: Potential and problems (pp. 3-19). Berkeley, CA: McCutchan.

Fry, R. (2007). The changing racial and ethnic composition of U.S. public schools. Washington, DC: Pew Hispanic Center, Pew Research Center.

Gaber, J., Gaber, S., Vincent, J., \& Boellstorff, D. (2004). An analysis of refugee resettlement patterns in the great plains (p. 719). Great Plains Research: A Journal of Natural and Social Sciences.

Gilblom, E. A., \& Sang, H. I. (2019). Schools as market-based clusters: Geospatial and statistical analysis of charter schools in Ohio. Education Policy Analysis Archives, 27(15). https://doi.org/10.14507/epaa.27.4091

Green, P. C. (2001). Racial balancing provisions and charter schools: Are charter schools out on a constitutional limb. Brigham Young University Education and Law Journal, 65.

Hageman, J. (2018, July 20). Number of English learner students grows in ND (p. A1). The Forum of Fargo-Moorhead.

Hair, J., Black, W., Babin, B., Anderson, R., \& Tatham, R. (2006). Multivariate data analysis (6th ed.). Upper Saddle River, NJ: Prentice-Hall International.

Hoxby, C. M. (1998). Analyzing school choice reforms that use America's traditional forms of parental choice. In P. E. Peterson \& B. C. Hassel (Eds.), Learning from school choice (pp. 133-156). Brookings Institution Press.

IRS. (2019, August 26). Immigration terms and definitions involving aliens. Retrieved from https://www.irs.gov/individuals/international-taxpayers/immigration-terms-and-definitions-involving-aliens

Knutson, J. (2003, February 1). School border measure gets flak. The Forum. Retrieved from https://digital.olivesoftware.com/Olive/APA/ForumOfFargoMoorhead/Print.Article.aspx?mode=text\&href= FORUM/2003/02/01\&id=Ar00102

Kotok, S., Frankenberg, E., Schafft, K. A., Mann, B. A., \& Fuller, E. J. (2017). School choice, racial segregation, and poverty concentration: Evidence from Pennsylvania charter school transfers. Educational Policy, 31(4), 415-447. https://doi.org/10.1177/0895904815604112447.

Lacireno-Paquet, N., Holyoke, T. T., Moser, M., \& Henig, J. R. (2002). Creaming versus cropping: Charter school enrollment practices in response to market incentives. Educational Evaluation and Policy Analysis, 24(2), 145-158. https://doi.org/10.3102/01623737024002145

Langenkamp, A. G., \& Carbonaro, W. (2018). How school socioeconomic status affects achievement growth across school transitions in early educational careers. Sociology of Education, 91(4), 358-378. https://doi.org/10.1177/0038040718802257

Linn, R. L., \& Welner, K. G. (Eds.). (2007). Race-conscious policies for assigning students to schools: Social science research and the Supreme Court cases. Washington, DC: National Academy of Education.

McMullen, C. (2016). New Americans: Refugees in Fargo-Moorhead. Retrieved November 23, 2019, from https://newamericanfm.wixsite.com/read. 
Mickelson, R. A., Bottia, M., \& Southworth, S. (2008). School choice and segregation by race, class, and achievement. Boulder, CO: National Education Policy Center. Retrieved from $\mathrm{http}: / /$ nepc.colorado.edu/publication/school-choice-and-segregationrace-class-and-achievement

Nathan, J. (1996). Charter schools: Creating hope and opportunity for American education (1st ed., Jossey-Bass education series). San Francisco, CA: Jossey-Bass.

National Center for Education Statistics. (2019a). Status and Trends in the Education of Racial and Ethnic Groups. Retrieved from https://nces.ed.gov/programs/raceindicators/indicator_RAA.asp

National Center for Education Statistics. (2019b). Common core of data public elementary/secondary school universe survey: school year 2008-2018. Washington, DC: US Department of Education, National Center for Education Statistics.

NDSU Archives. (2019). The Northern Pacific Railroad Moves West. Retrieved from https://library.ndsu.edu/fargo-history/?q=content/northern-pacific-railroad-moves-west.

Noltemeyer, A. L., Ward, R. M., \& Mcloughlin, C. (2015). Relationship between school suspension and student outcomes: A meta-analysis. School Psychology Review, 44(2), 224-240. https://doi.org/10.17105/spr-14-0008.1

North Dakota Census Office. (2017). North Dakota's Increasing Racial and Ethnic Diversity. North Dakota's Increasing Racial and Ethnic Diversity (August 2017). Bismarck, ND: North Dakota Department of Commerce.

Olson, D. (2019, December 2). Cass County leaders vote to continue refugee resettlement. The Forum. Retrieved from

https://www.inforum.com/news/government-and-politics/4796074-Cass-County-leaders-vote-to-continue-re fugee-resettlement

Orfield, G. (2009). Reviving the goal of an integrated society: A 21st century challenge. Los Angeles: Civil Rights Project/Proyecto Derechos Civiles, UCLA.

Orfield, G., \& Eaton, S. (1997) Dismantling desegregation: The quiet reversal of Brown v. Board of Education. New York, NY: New Press.

Orfield, G., Ee, J., Frankenberg, E., \& Siegel-Hawley, G. (2016). Brown at 62: School segregation by race, poverty and state. Los Angeles, CA: Civil Rights Project / Proyecto Derechos Civiles, UCLA.

Orfield, G., \& Frankenberg, E. (2014). Increasingly segregated and unequal schools as courts reverse policy. Educational Administration Quarterly, 50(5), 718-734. https://doi.org/10.1177/0013161X14548942

Orfield, G., \& Lee, C. (2005). Why segregation matters: Poverty and educational inequality. Cambridge, MA: Harvard University, The Civil Rights Project.

Orfield, M., \& Luce, T. F. (2009). Region: Planning the future of the Twin Cities. Minneapolis, MN: University of Minnesota Press.

Owens, A., Reardon, S. F., \& Jencks, C. (2016). Income segregation between schools and school districts. American Educational Research Journal, 53(4), 1159-1197. https://doi.org/10.3102/0002831216652722

Pool, C. (2017, November 21). West Fargo school district continues to deliberate elementary boundary realignment (p. C4). The Forum of Fargo-Moorhead.

Reardon, S. F., Grewal, E. T., Kalogrides, D., \& Greenberg, E. (2012). Brown fades: The end of court - ordered school desegregation and the resegregation of American public schools. Journal of Policy Analysis and Management, 31(4), 876-904. https://doi.org/10.1002/pam.21649

Reuer, W. (2017, January 20). More than 200 West Fargo students to change schools in 2017-2018. The Forum. Retrieved from https://www.inforum.com/news/4195963-more-200-west-fargo-students-change-schools-2017-18

Richards, M. P. (2014). The gerrymandering of school attendance zones and the segregation of public schools: A geospatial analysis. American Educational Research Journal, 51(6), 1119-1157. https://doi.org/10.3102/0002831214553652

Saporito, S., \& Sohoni, D. (2006). Coloring outside the lines: Racial segregation in public schools and their $\begin{array}{lllll}\text { attendance } \quad \text { boundaries. } & \text { Sociology }\end{array}$ https://doi.org/10.1177/003804070607900201 
School District Boundary Changes, ND Stat. §§ 15-47-43; 15-53.1-02 (1973).

Siegel-Hawley, G. (2013). Educational gerrymandering? Race and attendance boundaries in a racially changing suburb. Harvard Educational Review, 83, 580-612. https://doi.org/10.17763/haer.83.4.k385375245677131

Singer, A., \& Wilson, J. H. (2006). From 'there' to 'here': Refugee resettlement in Metropolitan America. Washington, DC: Metropolitan Policy Program, Brookings Institution.

Sohoni, D., \& Saporito, S. (2009). Mapping school segregation: Using GIS to explore racial segregation between schools and their corresponding attendance areas. American Journal of Education, 115(4), 569-600. https://doi.org/10.1086/599782

Swanson, C. B. (2004). Sketching a portrait of public high school graduation: Who graduates? Who doesn't? In G. Orfield (Ed.), Dropouts in America: Confronting the graduation rate crisis (pp. 13-40). Harvard Education Press.

Tabachnick, B. G., \& Fidell, L. S. (2013). Using multivariate statistics (6th ed.). Boston, MA: Pearson.

The City of Fargo. (2019). A Brief Glimpse into Fargo's Early History. Retrieved November 21, 2019, from http://fargond.gov/explore/about-fargo/city-history

Thernstrom, A., \& Thernstrom, S. (2004). No excuses: Closing the racial gap in learning. New York, NY: Simon \& Schuster.

United Nations High Commissioner for Refugees. (2019). The 1951 Refugee Convention. Retrieved from https://www.unhcr.org/en-us/1951-refugee-convention.html

U.S. Census Bureau. (2019a). U.S. Census Bureau QuickFacts: United States; Fargo City, North Dakota; West Fargo City, North Dakota. Retrieved from https://www.census.gov/quickfacts/

U.S. Census Bureau. (2019b). Glossary: Block groups. Retrieved from https://www.census.gov/programs-surveys/geography/about/glossary.html\#par_textimage_4

Welch, K., \& Payne, A.A. (2010). Racial threat and punitive school discipline. Social Problems, 57(1), 25-48. https://doi.org/10.1525/sp.2010.57.1.25

Wells, A. S. (2009) The social context of charter schools. In M. Berends, M. Springer \& Ballou (Eds.), Handbook of research on school choice (pp. 155-178). New York, NY: Routledge.

West Fargo Public Schools. (2019). West Fargo Public Schools: The District of Choice Since 1876. Retrieved from https://www.west-fargo.k12.nd.us/domain/121

Wolf, P. J., Howell, W. G., \& Peterson, P. E. (2000). School choice in Washington, DC: An evaluation after one year. Cambridge, MA: Harvard University, Program on Education, Policy and Governance.

Yun, J. T., \& Reardon, S. F. (2005). Private school racial enrollments and segregation. In J. T. Scott (Ed.), School choice and diversity: What the evidence says (pp. 42-58). New York, NY: Teachers College Press.

\section{Copyrights}

Copyright for this article is retained by the author, with first publication rights granted to the journal.

This is an open-access article distributed under the terms and conditions of the Creative Commons Attribution license (http://creativecommons.org/licenses/by/4.0/). 